\title{
Peran Workplace Well-being terhadap Mental Health: Studi pada Karyawan Disabilitas
}

\author{
Fridayanti, N. Kardinah, Tyas Julianti Nurul Fitri \\ Fakultas Psikologi, UIN Sunan Gunung Djati Bandung, Indonesia \\ e-mail: fridayanti@uinsgd.ac.id
}

\begin{abstract}
Employees with disability are still relatively few in the company. When disability employees have to work in tandem with normal employees, there might be a different treatment from their normal coworkers. This different treatment could have an impact on psychological conditions especially on mental health and workplace well-being of employee with disability. This study examined the effect of workplace well-being on mental health in employee with disability. The study was conducted at a company located in Garut, West Java. The participants were 70 employees with disability (30 men and 40 women). The researcher used Workplace Well-being Questionnaire and General Health Questionare (GHQ-12). Data were analyzed using simple regression analysis. The results showed that there was an effect of workplace well-being on mental health.
\end{abstract}

Keywords: workplace well-being, mental health, employees with disability

\begin{abstract}
Abstrak
Karyawan disabilitas masih terhitung sedikit yang dilibatkan bekerja di perusahaan. Ketika karyawan disabilitas harus bekerja bersama-sama dengan karyawan normal tentunya akan ada sedikit perlakuan berbeda dari rekan kerja normalnya. Hal itu akan berakibat pada keadaan psikis khususnya pada kesehatan mental dan kenyamanan karyawan disabilitas ketika berada di tempat kerja. Penelitian ini bertujuan untuk meneliti peranan dari workplace well-being terhadap mental health pada karyawan disabilitas. Metode penelitian menggunakan kuantitatif korelasional. Penelitian dilakukan di sebuah perusahaan yang berlokasi di wilayah Garut, Jawa Barat. Partisipan sebanyak 70 orang karyawan disabilitas (30 orang laki-laki dan 40 orang perempuan). Alat ukur menggunakan Workplace Well-being dan General Health Questionnaire (GHQ-12) untuk mengukur kesehatan mental. Analisis data menggunakan analisis regresi linier sederhana. Hasil penelitian menunjukkan adanya pengaruh workplace well-being terhadap mental health.
\end{abstract}

Kata Kunci: workplace well-being, mental health, karyawan disabilitas

\section{Pendahuluan}

Kesehatan mental yang baik memungkinkan orang untuk menyadari potensi mereka dalam mengatasi tekanan kehidupan yang normal, bekerja secara produktif dan berkontribusi pada komunitas mereka. Kondisi mental yang sehat pada tiap individu tidak dapat disamaratakan. Kondisi ini semakin memperkuat urgensi pembahasan kesehatan mental yang mengarah pada bagaimana memberdayakan individu, keluarga, maupun komunitas untuk mampu menentukan, menjaga dan mengoptimalkan kondisi kesehatan mentalnya dalam melakukan aktivitas sehari-hari (Harnois \& Gabriel, 2002).

Kesehatan mental di tempat kerja sering terabaikan, padahal sudah lama diketahui bahwa kesehatan pekerja merupakan faktor kunci dalam menentukan efektivitas jangka panjang organisasi. Kesehatan mental dapat berakibat pada kualitas perusahaan dalam mencapai tujuan ataupun target yang diharapkan (OECD, 2010). Banyak penelitian menunjukkan hubungan langsung antara tingkat produktivitas dengan kesehatan umum dan kesejahteraan tenaga kerja (Harnois \& Gabriel, 2002). 
Disamping persoalan kesehatan fisik, faktor kesehatan mental karyawan harus juga diperhatikan. Kesehatan mental adalah suatu kondisi yang seimbang antara kondisi fisik dengan psikis disebabkan keduanya saling berhubungan dan saling menguatkan antara satu dengan yang lainnya, sehingga dapat membantu individu beradaptasi dengan lingkungan sekitarnya (Goldberg, 1972).

Kesehatan mental penting dibahas karena terkait dengan luaran yang dihasilkan. Sebuah penelitian dilakukan oleh Gabriel dan Liimatainen pada 5 negara yang memiliki pasar tenaga kerja yang tergolong cukup besar yaitu Firlandia, Jerman, Inggris, Polandia, dan Amerika Serikat, menunjukkan bahwa kesehatan mental di tempat kerja sangat berperan penting dalam mencapai tujuan perusahaan. Masalah kesehatan mental karyawan akan berdampak pada produktivitas perusahaan dan pengeluaran biaya medis menjadi membengkak (Gabriel \& Liimatainen, 2000).

Dewasa ini, perusahaan dan organisasi semakin menyadari perlunya menangani kesejahteraan pekerja mereka secara serius. Organisasi yang progresif melakukannya karena mereka menghargai bahwa sumber daya terpenting adalah sumber daya manusia, yaitu para karyawan yang bekerja di perusahaan mereka. Organisasi lain mulai menangani masalah kesejahteraan karena semakin jelas ditemukan banyak masalah di tempat kerja disebabkan kurangnya komitmen organisasi terhadap kebutuhan pekerja mereka. Kurangnya pengakuan akan kebutuhan untuk meningkatkan kesejahteraan pekerja dapat meningkatkan masalah di tempat kerja, seperti stres, bullying, konflik, penyalahgunaan alkohol dan narkoba serta gangguan kesehatan mental (Harnois \& Gabriel, 2002). Untuk perusahaan, ada kerugian yang cukup besar terkait dengan masalah kesehatan mental seperti ketidakhadiran, berkurangnya produktivitas saat bekerja, yang turut berdampak buruk bagi produktivitas dan moral rekan kerja.

Meskipun terdapat konsekuensi yang signifikan, pada kenyataannya, pengusaha sering memiliki pemahaman yang buruk tentang masalah kesehatan mental. Masih banyak yang belum mengetahui apa yang dapat mereka lakukan untuk mempromosikan kesehatan mental yang baik di tempat kerja, termasuk intervensi dan dukungan awal ketika masalah kesehatan mental mulai muncul. Oleh karena itu, persoalan menjaga kesehatan mental yang baik di tempat kerja menjadi penting tidak hanya untuk kebijakan pemerintah, tetapi juga untuk produktivitas dan daya saing bisnis organisasi.

Kesehatan mental yang buruk terbukti berdampak pada karyawan. Persoalan kesehatan mental menjadi salah satu penyebab utama ketidakhadiran karyawan (Gabriel \& Liimatainen, 2000). Kesehatan mental buruk yang dialami oleh individu adalah penyebab signifikan masalah sosial dan kesehatan yang lebih luas, termasuk tingkat pencapaian pendidikan dan produktivitas kerja yang rendah, kohesi masyarakat yang buruk, tingkat kesehatan fisik, kematian dini, kekerasan, dan gangguan relasi interpersonal. Sebaliknya kesehatan mental yang baik mengarah pada gaya hidup lebih sehat, kesehatan fisik lebih baik, peningkatan pencapaian pendidikan dan produktivitas, serta tingkat kekerasan dan kejahatan yang lebih rendah (Eliot, 2016). Lebih lanjut, karyawan dengan masalah kesehatan mental, menghadapi tantangan tertentu di tempat kerja, termasuk konsekuensi potensial dari pengungkapan ataupun tidak mengungkapkan kondisi mereka, stigma dan diskriminasi (OECD, 2010).

Lebih lanjut disebutkan bahwa tempat kerja dan pekerjaan memainkan peran ganda dalam kesehatan mental karyawan. Kesehatan mental dapat menjadi sumber stres karena budaya, organisasi dan tuntutan tempat kerja; atau dapat menjadi sumber dukungan dan berkontribusi 
terhadap kesehatan mental secara keseluruhan dan proses pemulihan dari penyakit mental (OECD, 2010).

Workplace well-being adalah komponen yang paling dekat hubungannya dengan pekerja dan lingkungan kerja karena pekerja menghabiskan sebagian besar waktunya di lingkungan kerja. Page (2005) mendefinisikan workplace wellbeing sebagai kesejahteraan yang dirasakan oleh pegawai yang dipengaruhi oleh adanya kepuasaan terhadap aspek-aspek dalam pekerjaannya. Page (2005) juga menjelaskan bahwa workplace well-being ini terdiri dari perasaan pekerja secara umum (core affect) dan nilai kerja (work values) atau aspek-aspek penting yang ada dalam pekerjaannya. Ahli lain menjelaskan bahwa workplace well-being mencakup pengukuran terhadap kesejahteraan berdasarkan pengalaman hidup dan pengalaman yang berkaitan dengan pekerjaan (Danna \& Griffin, 1999).

Berdasarkan pemaparan di atas maka workplace well-being mencakup sebuah persepsi mengenai kesejahteraaan yang dirasakan terhadap aspek-aspek terkait pekerjaan dan lingkungan pekerjaan. Secara spesifik terkait dengan semua aspek kehidupan kerja, mulai dari kualitas dan keamanan lingkungan fisik, hingga bagaimana perasaan pekerja tentang pekerjaan mereka, lingkungan kerja mereka, iklim di tempat kerja dan organisasi kerja. Tujuan tindakan untuk kesejahteraan di tempat kerja adalah untuk melengkapi langkah-langkah keselamatan pekerja untuk memastikan pekerja aman, sehat, puas dan terlibat di tempat kerja (Harnois \& Gabriel, 2000).

Konsep workplace well-being sangat penting tidak hanya untuk akademisi dan peneliti, melainkan juga manajer dan tentunya bagi para eksekutif yang memberikan link untuk pekerjaan seharihari dan pengalaman hidup dari semua anggota organisasi. Literatur dari berbagai bidang, seperti perilaku organisasi, psikologi, dan kedokteran, berkontribusi pada pemahaman terpadu tentang kesejahteraan di tempat kerja. Bahkan beberapa model menarik disajikan dari perspektif interdisipliner (Simone, 2014).

Perubahan-perubahan dalam lingkungan kerja, serta ketidakamanan dalam pekerjaan yang sebagian besar diciptakan oleh krisis ekonomi global, mungkin dapat berkontribusi terhadap peningkatan stres di tempat kerja. Stres kerja telah dikaitkan dengan berbagai efek buruk pada kesehatan mental dan fisik. Selain itu, lingkungan tempat kerja yang baru menuntut kompetensi sosial dan keterampilan berkomunikasi lebih besar, sehingga kekurangan yang terkait dengan kompetensi ini adalah elemen umum dari masalah kesehatan mental. Hal ini cenderung menempatkan individu untuk mengalami atau berisiko mengalami masalah kesehatan mental di tempat kerja modern (OECD, 2010).

Penelitian pada pekerja pabrik menunjukkan bahwa semakin baik dukungan organisasi yang dipersepsi oleh pekerja pabrik, semakin baik pula tingkat kesejahteraan (workplace well-being) yang dirasakan pekerja pabrik di tempat kerjanya (Sawitri dkk., 2013). Penelitian lain menemukan terdapat hubungan positif yang signifikan antara workplace well-being dan work locus of control pada karyawan perusahaan manufaktur. Dengan demikian, semakin bersifat internal orientasi locus of control maka semakin tinggi pula workplace well-being pada karyawan perusahaan manufaktur, begitu pula sebaliknya (Restika, 2013). Dalam penelitian lain (Sadana \& Vany, 2014) diperoleh hasil bahwa workplace wellbeing secara parsial berpengaruh negatif terhadap turnover intention yang artinya jika workplace well-being semakin meningkat maka turnover intention akan menurun. Hasil lainnya dalam penelitian tersebut menunjukkan bahwa employee engagement dan workplace well-being secara bersama-sama berpengaruh terhadap turnover intention. 
Kesehatan dan kesejahteraan pekerja harus menjadi perhatian. Saat ini terdapat kesadaran yang semakin besar bahwa elemen tempat kerja menimbulkan risiko bagi pekerja. Danna dan Griffin (1999) mencatat beberapa hal terkait tempat kerja seperti karakteristik tempat kerja mulai dari praktik kesehatan dan keselamatan oleh organisasi, masalah dasar yang terkait dengan desain ergonomic dapat memiliki konsekuensi-konsekuensi besar bagi pekerja. Ancaman potensial lainnya termasuk peningkatan agresi di tempat kerja, balas dendam dan kekerasan, serta pelecehan seksual dan bentuk lain perilaku disfungsional. Selanjutnya disebutkan bahwa kesehatan dan kesejahteraan juga penting karena konsekuensinya bagi para pekerja.

Para peneliti dan manajer umumnya mengakui bahwa kesehatan dan kesejahteraan dapat berpotensi memengaruhi pekerja dan organisasi dengan cara negatif. Misalnya, pekerja yang mengalami kesehatan dan kesejahteraan buruk di tempat kerja mungkin kurang produktif, membuat keputusan dengan kualitas rendah, lebih rentan tidak hadir di tempat kerja dan secara konsisten mengurangi kontribusi total untuk organisasi. Untuk individu, banyak kerugian fisiologis, psikologis, serta emosional yang dapat timbul. Pada gilirannya kesehatan juga dipandang sebagai subkomponen kesejahteraan dan terdiri dari kombinasi indikator psikologis seperti pengaruh frustrasi dan kecemasan dengan indikator fisik seperti tekanan darah dan kesehatan fisik umum. Kesehatan dan kesejahteraan dapat merujuk pada aspek mental, psikologis, atau emosional pekerja seperti yang ditunjukkan oleh keadaan emosional dan tingkat epidemiologis penyakit mental (Danna \& Griffin, 1999).

Smith dkk. (1995) sebagaimana dikutip oleh Danna dan Griffin (1999) mengidentifikasi tiga bidang utama penelitian yang menghubungkan kehidupan organisasi dengan kesehatan pekerja yaitu:
1) hubungan pengaturan kerja dengan risiko penyakit tertentu; 2) hubungan stres dengan kondisi kerja; dan 3) kerentanan penyakit tertentu dengan karakteristik kepribadian atau jenis lingkungan kerja. Jenis lingkungan kerja telah ditemukan terkait dengan risiko kesehatan tertentu, termasuk yang melibatkan situasi darurat dan pemutusan hubungan kerja.

Selaras dengan pernyataan di atas bahwa lingkungan kerja berperan dalam berbagai aspek salah satunya kenyamanan di tempat kerja (workplace well-being). WHO mencanangkan visi dari rencana aksi kesehatan mental dunia 2013-2020 yaitu dimana kesehatan mental dihargai, dipromosikan, dan dilindungi, gangguan mental dicegah dan orang yang terkena gangguan ini dapat melakukan berbagai hak asasi manusia dan mendapat akses kesehatan kualitas tinggi, sesuai budaya dan pelayanan sosial pada waktu yang tepat untuk mendorong pemulihan, yang memungkinkan untuk mencapai kesehatan pada level tertinggi dan berpartisipasi sepenuhnya dalam masyarakat dan di tempat kerja, serta bebas dari stigmatisasi dan diskriminasi.

Saat ini, peran serta dalam dunia industri tidak hanya untuk kalangan orang yang memiliki kesempurnaan fisik. Bagi orang yang memiliki keterbatasan seperti penyandang disabilitas juga memiliki kesempatan yang sama. Dalam hal ini pemerintah mengeluarkan Undang-undang (UU) nomor 8 tahun 2016 tentang penyandang disabilitas (Undang-Undang Republik Indonesia No. 8 Tahun 2016 tentang Penyandang Disabilitas, 2016). Pandangan di dalam UU penyandang cacat yang sudah lama berjalan ini kemudian dipandang sudah ketinggalan zaman dan tidak sesuai dengan upaya peningkatan harkat dan martabat penyandang disabilitas sebagai manusia seutuhnya (Ratnaningsih, 2016). Penyandang disabilitas didudukkan sebagai subjek yang artinya sebagai individu yang memiliki hak dan kewajiban sehingga penyelenggaraan kesejahteraan 
sosial untuk penyandang disabilitas tidak hanya berupa rehabilitasi sosial dan jaminan sosial namun juga meliputi pemberdayaan sosial dan perlindungan sosial (Ratnaningsih, 2016).

Lingkungan kerja memainkan peran penting dalam kehidupan manusia. Lingkungan kerja tidak hanya menjadi tempat mencari nafkah, ajang persaingan bisnis, dan peningkatan kesejahteraan hidup, tetapi juga menjadi sumber stres yang memberikan dampak negatif terhadap kesehatan mental bagi semua orang yang berinteraksi di tempat tersebut (Mulyadi, 2017). Tempat kerja yang sehat sangat penting untuk kesehatan fisik dan psikologis semua pegawai layanan publik, karena itu memungkinkan mereka untuk membawa yang terbaik dari beragam bakat, keterampilan, dan energi mereka saat mereka memberikan layanan (UndangUndang Republik Indonesia No. 18 tahun 2014 tentang Kesehatan Jiwa, 2014). Kesehatan mental karyawan disabilitas harus juga diperhatikan. Penelitian ini bertujuan untuk meneliti pengaruh workplace well-being terhadap mental health penyandang disabilitas.

\section{Metode Penelitian}

Penelitian ini menggunakan metode kuantitatif korelasional. Partisipan dalam penelitian ini adalah karyawan disabilitas di PT. Changsin Reksa Jaya, sebuah perusahaan garmen berlokasi di Garut, Jawa Barat. Mereka bekerja pada line pencetakan (printing) dan menjahit. Jumlah partisipan sebanyak 70 orang, terdiri dari 30 orang laki-laki dan 40 orang perempuan. Responden dipilih berdasarkan data dari perusahaan. Semua karyawan yang termasuk dalam daftar disabilitas dilibatkan sebagai responden penelitian. Untuk memperoleh informasi yang dibutuhkan, peneliti membagikan alat ukur berupa kuesioner dengan skala likert. Pada tiap item disediakan enam alternatif jawaban, yaitu SS (sangat sesuai), S (sesuai), AS (agak sesuai), ATS (agak tidak sesuai), TS (tidak sesuai), dan STS (sangat tidak sesuai). Variabel workplace well-being menggunakan skala workplace well-being index yang dibuat berdasarkan pada dua aspek yang dikemukakan oleh Page (2005) yaitu aspek intrinsik dan ekstrinsik. Dalam hal ini peneliti mengadaptasi alat ukur yang dikembangkan oleh Kurniadewi (2016) yang memiliki validitas .949 sampai dengan .983 serta reliabilitas .943 . Variabel mental health menggunakan alat ukur GHQ-12 (general health questionnaire-12) yang dikembangkan oleh Goldberg dan Hillier (1979) terdiri dari tiga aspek yaitu social disfunction, anxiety and depression, dan loss of confindence. Peneliti menggunakan alat ukur GHQ-12 versi Indonesia yang dibuat oleh Primasari dan Hidayat (2016) yang memiliki validitas .752 sampai dengan .897 serta reliabilitas .734 .

Data penelitian dianalisis secara deskriptif maupun inferensial. Analisis kategorisasi merupakan gambaran deskriptif dari masing-masing variabel yaitu workplace well-being dan mental health yang dikategorikan menjadi tiga kategori yaitu rendah, sedang, dan tinggi, berdasarkan nilai mean dan standar deviasi. Selanjutnya pengujian hipotesis dilakukan melalui analisis regresi linier sederhana.

\section{Hasil Penelitian dan Pembahasan}

Diperoleh deskripsi umum untuk skala workplace well-being mempunyai mean sebesar 226.31 dan standar deviasi sebesar 18.541, sedangkan untuk skala mental health mempunyai mean sebesar 39.66 dan standar deviasi sebesar 2.707. Berdasarkan hasil uji asumsi klasik data berdistribusi normal dan terjadi linieritas antar variabel.

Tabel 1

Uji Regresi Linier Sederhana

\begin{tabular}{lccccc}
\hline \multicolumn{5}{c}{$\begin{array}{c}\text { Unstandardized } \\
\text { Coefficients }\end{array}$} & $\begin{array}{c}\text { Standardized } \\
\text { Coefficients }\end{array}$ \\
Model & $B$ & Etd. & & & \\
\hline $1($ Const $)$ & 61.848 & 26.269 & Beta & $t$ & Sig. \\
MH & 4.147 & .661 & .606 & 6.275 & .000 \\
\hline
\end{tabular}


Tabel 2

Koefisien Determinasi

\begin{tabular}{ccccc}
\hline $\begin{array}{c}\text { Mo- } \\
\text { del }\end{array}$ & $R$ & $\begin{array}{c}R \\
\text { Square }\end{array}$ & $\begin{array}{c}\text { Adjusted } R \\
\text { Square }\end{array}$ & $\begin{array}{c}\text { Std. Error of } \\
\text { the Estimate }\end{array}$ \\
\hline 1 & $.606^{\mathrm{a}}$ & .367 & .357 & 14.863 \\
\hline
\end{tabular}

Berdasarkan hasil uji regresi linier sederhana pada tabel 1, diperoleh nilai signifikansi sebesar .000 yang mana nilai tersebut lebih kecil dibandingkan nilai alpha yaitu .050, yang berarti terdapat pengaruh workplace well-being terhadap mental health pada karyawan disabilitas PT. Changsin Reksa Jaya. Selain itu diperoleh nilai koefisien determinasi sebesar .367 sebagaimana disajikan pada tabel 2. Hal ini berarti bahwa $36.7 \%$ workplace well-being dipengaruhi oleh mental health. Sedangkan sisanya $63.3 \%$ dipengaruhi oleh variabel lain yang tidak diteliti pada penelitian ini.

Pada penelitian ini, beberapa data demografi yang dapat dijelaskan dari mayoritas responden adalah: 1) berjenis kelamin perempuan sebanyak 40 orang $(57.15 \%)$; 2) memiliki rentang usia $21-25$ tahun; 3) tingkat pendidikan lulusan SMP sebanyak 40 orang $(57.15 \%)$; 4) berstatus belum menikah sebanyak 55 orang (78.57\%); bekerja pada line printing sebanyak 35 orang (50\%); serta 5) lama bekerja pada rentang 6 bulan - 1 tahun sebanyak 38 orang (54.29\%). Terkait dengan suku bangsa, semua responden merupakan suku Sunda. Selain itu penghasilan perbulan semua responden juga sama, karena perusahaan menetapkan gaji dengan upah minimum regional (UMR) Kabupaten Garut sebesar Rp. $1,807,000$.

Jika dilihat dari deskripsi kategori tiap variabel, dapat diketahui bahwa workplace well-being pada karyawan disabilitas PT. Changsin Reksa Jaya tergolong sedang yaitu sebanyak 53 responden atau sebesar $75.71 \%$. Demikian pula mental health pada karyawan disabilitas PT. Changsin Reksa Jaya sebanyak 53 responden atau sebesar
$75.71 \%$ termasuk ke dalam kategori sedang. Hal tersebut menunjukkan mental health pada karyawan disabilitas ini cukup baik.

Hasil ini selaras dengan pernyataan Kelloway dan Barling (1991) serta De Lange dkk. (2004) yang menyebutkan bahwa lingkungan kerja (workplace wellbeing) dapat memberikan dukungan terhadap kesejahteraan dan dengan adanya kesehatan mental kerja, karyawan akan memiliki mental health yang optimal. Hasil ini juga mendukung pernyataan Page (2010) bahwa diantara salah satu komponen inti mental health karyawan adalah workplace well-being yang mana hal-hal yang berhubungan dengan pekerjaan menjadi hal-hal yang dapat berpengaruh terhadap mental health karyawan.

Sejalan pula dengan yang dikemukakan oleh Organization for Economic Co-operation and Development (OECD, 2010) bahwa tempat kerja/ lingkungan kerja memainkan peran ganda dalam mental health karyawan yaitu dapat menjadi sumber stres karena budaya organisasi dan tuntutan di tempat kerja atau sebaliknya dapat menjadi sumber dukungan dan berkontribusi terhadap mental health secara keseluruhan. Lingkungan tempat kerja yang negatif dapat membuat karyawan tidak bisa bekerja. Tempat kerja juga dapat berkontribusi untuk menjaga mereka tetap sehat dan cukup dukungan untuk terus bekerja.

Kornhauser (1965, dalam Page \& Vella-Brodrick, 2009) juga menyatakan bahwa faktor penentu mental health ditentukan oleh faktor di lingkungan kerja maupun di luar lingkungan kerja. Faktor di lingkungan pekerjaan seperti pekerjaan yang overload, atau terjadinya konflik dengan orang-orang yang berada di lingkungan pekerjaan tersebut. Sedangkan faktor di luar lingkungan pekerjaan seperti masalah keluarga, kesehatan, dan interaksi variabel kerja. Hal ini selaras dengan jawaban responden terkait faktor di 
lingkungan pekerjaan yaitu seberapa nyaman responden mempersepsikan lingkungan sosial di tempat kerjanya, ratarata responden menjawab setuju bahwa lingkungan sosial tempat mereka bekerja nyaman. Sedangkan terkait faktor di luar lingkungan pekerjaan seperti seberapa banyak mereka mempunyai waktu dengan keluarga, rata-rata responden menjawab sangat setuju yang artinya mereka masih mempunyai waktu dengan keluarga mereka meskipun harus menyelesaikan pekerjaan yang diberikan atasan.

Selain peneliti di atas, Harter dkk. (2002) memberikan definisi terkait workplace well-being sebagai kesehatan mental karyawan yang dipengaruhi oleh pertumbuhan pribadi, tujuan hidup, hubungan positif dengan orang lain, penguasaan terhadap lingkungan, integrasi sosial, dan kontribusi sosial. Ini selaras dengan penelitian yang dilakukan. Pada beberapa item workplace well-being terkait kemandirian dalam bekerja, kondisi kerja dan nilai sebagai manusia, umumnya responden menjawab sangat setuju yang artinya responden mempersepsikan bahwa mereka dapat mandiri dalam bekerja, dihargai dan diperlakukan dengan baik oleh teman-teman yang berada dalam satu lingkungan dengan mereka khususnya atasan, dan merasa nyaman dengan kondisi kerja saat ini.

Selain faktor yang dikemukakan di atas, kompetensi dan kemampuan yang dimiliki karyawan menjadi salah satu tuntutan yang ada di lingkungan kerja. Hal itu juga dapat berpengaruh pada kesehatan mental karyawan. Keadaan karyawan disabilitas PT. Changsin Reksa Jaya ratarata sudah memiliki kemampuan yang dapat membantu untuk menyelesaikan pekerjaan yang diberikan oleh atasan kepada mereka. Hal ini karena mereka sejak menginjak bangku sekolah luar biasa, pihak sekolah menyediakan kesempatan bagi para siswa untuk dapat mengasah hard skill seperti menjahit. Dengan demikian ketika mereka bekerja pada suatu perusahaan yang berhubungan dengan menjahit mereka sudah mampu dan dapat mengerjakan pekerjaan dengan baik. Hal ini juga dapat dibuktikan melalui hasil wawancara dengan bagian human resources perusahaan yang menyatakan bahwa karyawan disabilitas cenderung lebih produktif dalam bekerja dan ulet ketika mereka diberikan tugas oleh atasan.

\section{Simpulan}

Berdasarkan analisa data diperoleh simpulan terdapat pengaruh signifikan workplace well-being terhadap mental health karyawan disabilitas pada PT. Changsin Reksa Jaya. Hasil penelitian ini dapat bermanfaat bagi pengambil kebijakan atau perusahaan agar dapat berkontribusi dalam hal penyediaan lapangan pekerjaan bagi para penyandang disabilitas. Penting juga diteliti lebih lanjut mengenai sikap dan perilaku kerja karyawan disabilitas, ataupun bagaimana respon karyawan lain dan atasan terkait keberadaan penyandang disabilitas.

\section{Daftar Pustaka}

Danna, K., \& Griffin, R. W. (1999). Health and well-being in the workplace: A review and synthesis of the literature. Journal of Management, 25(23), 357384.

De Lange, A. H., Taris, T. W., Kompier, M. A., Houtman, I. L., \& Bongers, P. M. (2004). The relationships between work characteristics and mental health: Examining normal, reversed and reciprocal relationships in a 4-wave study. An International Journal of Work, Health \& Organisations, 18(2).

Eliot, I. (2016, June). Poverty and mental health: A review to inform the Joseph Rowntree foundation's anti-poverty strategy. Mental Health Foundation.

Fikri, M. (2018). Pengaruh workplace wellbeing terhadap intensi turnover pada karyawan (Skripsi tidak diterbitkan). 
Universitas Muhammadiyah Malang, Fakultas Psikologi.

Gabriel, P., \& Liimatainen, M. (2000, January). Mental health in the workplace: Introduction, executive summaries. International Labour Office Geneva.

Goldberg, D. (1972). The detection of psychiatric illness by questionnaire. Oxford University Press.

Goldberg, D., \& Hillier, H. (1979). A scaled version of the General Health Questionnaire. Psychological Medicine, 9(1), 139-145.

Harnois, G., \& Gabriel, P. (2002). Mental health and work: Impact, issues and good practices. World Health Organization.

Harter, J. K., Schmidt, F. L., \& Keyes, C. L. M. (2002). Well-being in the workplace and its relationship to business outcomes: A review of the gallup studies. Dalam C. L. M. Keyes \& J. Haidt (Eds.), Flourishing: The positive person and the good life (hal. 205-224). American Psychological Association.

Kelloway, E. K., \& Barling, J. (1991). Job characteristics, role stress and mental health. Journal of Occupational Psychology, 64(2).

Kurniadewi, E. (2016). Psychological capital dan workplace well-being sebagai prediktor bagi employee engagement. Jurnal Psikologi Integratif, 4(2).

Mulyadi. (2017). Islam dan Kesehatan Mental. Retrieved from ://repository.uinib.ac.id/442/3/Bab\%20 1\%20s.d\%\%20Bab\%20VII\%20\%28Is1 am\%20dan\%20Kesehatan\%20Mental $\% 29 . P d f$

OECD. (2010). Expert Meeting Mental Health, Disability and Work, Paris, 26$28 \quad$ April 2010. https://www.oecd.org/els/45008308.pd $\mathrm{f}$

Page, K. (2005). Subjective wellbeing in the workplace (Thesis). School of
Psychology Faculty of Health and Behavioural Sciences Deakin University.

Page, K. M., \& Vella-Brodrick, D. A. (2009). The 'what', 'why' and 'how' of employee well-being: A new model. Social Indicators Research, 90(3), 441458.

Primasari, I., \& Hidayat, R. (2016). General Health Questionnaire-12 (GHQ-12) sebagai instrumen skrining gangguan penyesuaian. Jurnal Psikologi, 43(2).

Ratnaningsih, E. (2017, Pebruari 23). Pergeseran paradigma tentang penyandang disabilitas dalam UU No. 8 Tahun 2016. HYPERLINK "https://thebrele.wordpress.com/2017/0 2/23/pergeseran-paradigma-tentangpenyandang-disabilitas-dalam-uu-no-8tahun-2016/"

https://thebrele.wordpress.com/2017/0 2/23/pergeseran-paradigma-tentangpenyandang-disabilitas-dalam-uu-no-8tahun-2016/

Restika. (2013). Hubungan antara workplace well-being dengan work locus of control pada karyawan perusahaan manufaktur (Skripsi tidak diterbitkan). Universitas Indonesia, Fakultas Psikologi.

Sawitri, D. W., Parahyanti, E., \& Soemitro, L. J. (2013). Hubungan antara perceived organizational support dan workplace well-being pada pekerja pabrik (Skripsi tidak diterbitkan). Universitas Indonesia, Fakultas Psikologi.

Simone, S. D. (2014). The affective component of the workplace in organizational behaviour studies. American International Journal of Contemporary Research, 4(9), 38-43.

Sadana, S. MS., \& Vany, E. A. (2014). Pengaruh employee engagement dan workplace well-being terhadap turnover intention (Studi pada Kantor Akuntan Publik ABC \& Rekan). Jurnal Akuntansi dan Bisnis, 1(2). 
Undang-Undang Republik Indonesia No 4 tahun 1997 tentang penyandang Cacat. (1997).

http://www.bpkp.go.id/uu/filedownloa $\mathrm{d} / 2 / 46 / 442 . b p k p$

Undang-Undang Republik Indonesia No. 18 tahun 2014 tentang Kesehatan Jiwa. (2014). http://yankes.kemkes.go.id/assets/dow nloads/UU\%20No.\%2018\%20Th\%202 014\%20ttg\%20Kesehatan\%20Jiwa.pdf Undang-Undang Republik Indonesia No. 8 Tahun 2016 tentang Penyandang Disabilitas. (2016). http://pugpupr.pu.go.id/_uploads/PP/U U.\%20No.\%208\%20Th.\%202016.pdf 
Psympathic, Jurnal Ilmiah Psikologi Desember 2019, Vol. 6, No. 2, Hal. : 191-200 